\title{
Transforming (but not Transcending) the State System? On Statist
}

\section{Cosmopolitanism}

Luke Ulaş ${ }^{*}$

Philosophy and Law, Goethe University, Frankfurt

Can states become committed and competent agents of cosmopolitan justice? The theory of 'statist cosmopolitanism' argues that they can: their citizens can be turned towards a commitment to cosmopolitan principles and actions by moral entrepreneurs constituting a 'cosmopolitan avantgarde', and can be sustained in their commitment to those principles by their pre-existing attachment to the state as a political community. Taking cosmopolitan principles as axiomatic, this paper subjects statist cosmopolitanism to critique. First, I question the scale of the transformation that a cosmopolitan avant-garde can engender given the complexity of the causal chains the avant-garde seek to elucidate, as well as the countervailing potency of the state itself which reinforces particularistic attitudes in its citizens. Second, I argue that even if, contra my preceding argument, the cosmopolitan avant-garde were to be successful, states would find it desirable to federally integrate in order to be better able to realise their cosmopolitan commitments. Such integration is compatible with statist cosmopolitanism's motivational theory, even if not its institutional vision. Finally, I re-characterise the cosmopolitan avant-garde as agitators for the transcendence, rather than just transformation, of the state system.

Keywords: statist cosmopolitanism, cosmopolitanism, global justice, world state, global solidarity

\section{Introduction}

Cosmopolitans are often keen to emphasise that their principles do not necessitate any particular institutional architecture; cosmopolitanism is a moral outlook that informs the critique of political institutions, but is separable from any specific institutional proposal. Potentially, cosmopolitan principles are realisable from within the multi-state system that exists today, and certainly we should not think that moral cosmopolitanism entails 'political cosmopolitanism', where by the latter is often meant something like a world state (Beitz, 1999; Tan, 2004). However, the suggestion that cosmopolitan principles are realisable from within the state system may just seem like wishful thinking, especially when the case is also often made that it is that system that is in large part responsible for the global circumstances

\footnotetext{
*Ulas@em.uni-frankfurt.de
} 
that cosmopolitanism seeks to rectify. So do we have any positive reason to believe that the state system offers a promising institutional setting for the realisation of cosmopolitan principles, and indeed a more promising setting than potential alternatives?

The theory of statist cosmopolitanism says we do. It argues that states represent the most plausible agents of cosmopolitan justice, ${ }^{1}$ since they can draw upon certain hard-won communal and political resources that can potentially be put in the service of cosmopolitan ends. Key in this regard is the idea of a 'cosmopolitan avant-garde', who can play the role of instigating cosmopolitan transformations in the attitudes and behaviour of state populations, and ultimately the behaviour of states themselves. In what follows, I aim firstly to raise some doubts about the chances of success for a cosmopolitan avant-garde. Thereafter, and setting those doubts aside, I dissociate the idea of the cosmopolitan avant-garde from statist cosmopolitanism's institutional vision. Indeed, so I assert, in the unlikely event that the cosmopolitan avant-garde successfully inspire a global cosmopolitan transformation, they will do so whilst stimulating the transcendence - and not just the transformation - of the state system; in a world suitably attitudinally transformed, a federal world state is in fact a more plausible setting for the realisation of cosmopolitan justice than a multi-state system. ${ }^{2}$

The paper takes the following path. In the first section I briefly set out an initial case against the state system as an agent of cosmopolitan justice. The second section introduces statist cosmopolitanism as a strong challenge to the initial argument. The remaining three sections focus on the idea of the 'cosmopolitan avant-garde'. I consider, in the third section, whether the avant-garde can be successful in encouraging the cosmopolitan selfreinterpretation of states, and voice some scepticism. The fourth section argues that even if the cosmopolitan avant-garde were to be successful, movement toward a global federal order would be the rational consequence. Lastly, the fifth section reinterprets the cosmopolitan avant-garde as agitators for the usurpation of the domestic state system rather than merely its reinterpretation. The effect of these last two sections together is to make a case for separating the idea of the cosmopolitan avant-garde from the institutional vision of statist 
cosmopolitanism, and more strongly, tethering it instead to the prospect of global political integration.

\section{Arguments against states as agents of cosmopolitan justice}

Cosmopolitans have more often understood the state system as a contributing factor to global injustice than as a promising institutional environment for its resolution. At the most basic level, the very existence of multiple states claiming external sovereignty looks to be inherently anti-cosmopolitan: whilst cosmopolitanism is a universalistic theory, states are fundamentally particularistic entities that claim the sovereign right to discriminate between members and non-members. Since some states are much more powerful and richer than others, those who are excluded from better-off states are comparatively disadvantaged, and indeed are often desperately poor in absolute terms.

That some states are currently better off than others doesn't in itself tell us that cosmopolitan justice couldn't be realised from within the state system, of course. Yet this further claim is also made, and is often informed by some form of 'realist' theorising; rather than pursue cosmopolitan justice, states inevitably pursue their own interests (e.g. Kamminga, 2006). Resultantly, more powerful states will, for example, manipulate international organisations, such as the WTO, in line with their own advantage (Moellendorf, 2005; Steinberg, 2002). Pursuit of state self-interest inevitably also leads to collective action problems with respect to the delivery of global public goods like the avoidance of climate change, the preservation of fish stocks, combating the spread of disease, international peace, and, so we might add, the realisation of global justice. ${ }^{3}$

Moreover, one can question the very notion that states are appropriately chargeable with duties of cosmopolitan justice, even assuming that cosmopolitan principles are normatively defensible. After all, what is the purpose of the state? One answer to this question is to say that the state is a type of association, and that the best way to determine the purpose of an association is to ask its members what they see as its purpose. Another way of putting this is that the state should operate according to the will of its people. But to date the declared 
will of the people has reliably been that a state's government should pursue the interests of its own citizens; the 'national interest'. These days the 'national interest' is typically translated by politicians into a demand for economic growth; the pursuit of an ever-increasing Gross Domestic Product (GDP). The demand is not for globally increasing gross product (other than insofar as this is instrumentally beneficial for domestic gain), but for increasing GDP in this state. This can be understood as a concern for absolute gain, but it also by extension tends to involve the pursuit of relative gain, i.e. the seeking of advantage over other states. Increasing the GDP of one state frequently involves, for example, making exports globally competitive, attracting businesses that may have built plants elsewhere, and so on. It has also tended to involve more coercive and exploitative inter-state practices, that establish and solidify the power of some states over others, and that are by and large consented to, at least tacitly, by benefiting populations (Pogge, 2002). Citizens, then, do not currently understand their state as an agent of cosmopolitan justice - rather, many explicitly conceive of their state as in competition with other states, and thus understand part of its purpose as the seeking of comparative advantage over those other states.

As well as the 'national interest', citizens also often care about social justice. Indeed, an alternative (but compatible) understanding of the purpose of the state could be the establishment of just relationships between citizens. But then another problem seems potentially to be presented by the apparent conflict between a state's pursuit of internal justice (i.e. structuring relationships between its citizens in a just manner) and the realisation of cosmopolitan justice. For example, if a well-off but unjustifiably internally unequal state's government invests large sums of money in its more deprived regions in an effort to ease that internal inequality, it might, by that very act, be acting unjustly from a cosmopolitan perspective, since globally there are individuals suffering far worse forms of poverty than that suffered by its own citizens. On the other hand, a state government that instead spent that money relieving severe poverty overseas might also be committing an injustice by passing over social injustice at home, the alleviation of the latter being its purpose in existing. 
What follows from these considerations is that it is possible to argue that it would be illegitimate for state governments to seek to realise cosmopolitan principles, even if doing so is a demand of justice. We might then characterise the state as an inherently unjust institution from a cosmopolitan perspective, but it is precisely because of this fact that it represents an inappropriate agent of cosmopolitan justice: it just can't take on the role the cosmopolitan wants to assign to it without betraying itself. Is a crime syndicate appropriately chargeable with duties to obey the law? Normatively speaking, yes it is. But in another sense, the assignment of this duty just doesn't make sense given that the very reason that that corporate agent exists is to benefit by breaking the law. Expecting a crime syndicate not to break the law is in fact to expect the impossible - the only way it can comply is to cease being a crime syndicate. Similarly, on an understanding of states as inevitable servers of their own citizens' interests, the only way that states could coherently aid the realisation of distributive cosmopolitanism would be by dissolving themselves. If the purpose of the state is alternatively, or also, the pursuit of domestic social justice, then the worry is that in prioritising global injustice, states may illegitimately overlook injustices at home that it is their purpose to alleviate.

\section{Statist cosmopolitanism}

Given the above, what basis is there to expect the state system to be a promising site for the realisation of cosmopolitan justice? The theory of statist cosmopolitanism offers an answer. For statist cosmopolitanism, the state represents the most plausible agent of cosmopolitan justice because, as an already established political community, it has various resources at its disposal that are absent at transnational and global levels and that can potentially be harnessed in service of cosmopolitan ends.

Statist cosmopolitanism understands the state as comprising a cohesive historical community, featuring shared cultural reference points and 'schemes of understanding', to which its citizens are emotionally attached. In an echo of communitarian theorising, it is understood to be within this context that persons' moral norms are learnt and that moral 
action is motivationally sustainable. But the statist cosmopolitan denies that this must necessarily mean that moral principles remain inwardly focussed and particularist. Indeed, the political community of the state is best understood as a 'unique social entity in dynamic development', rather than as a static entity with a rigid self-understanding and moral commitments (Ypi, 2008, p. 59). It is an entity that collaboratively builds upon its historical experiences and shared understandings to reach new interpretations of itself. On account of this pre-existing attachment, radical change is motivationally plausible, potentially in a cosmopolitan direction:

Imperatives flowing from the new interpretations of the point and purpose of shared institutions would in this case not appear over-demanding and citizens would not comply simply out of fear of coercive mechanisms. They would do so as part of their allegiance to political institutions to whose development they have contributed (Ypi, 2011, p. 152).

In other words, where a cosmopolitan transformation of a state occurs, it will be recognised as a collective reinterpretation of the purpose of the political community to which one is already emotionally attached, and will thus contain its own source of motivational stability. By contrast, those who recommend some form of political cosmopolitanism, rejecting domesticlevel affective attachments as straightforwardly anti-cosmopolitan, not only ignore political reality in a counterproductive manner (cf. Brown, 2011), but also overlook a potentially potent source of cosmopolitan motivation.

By asserting the possibility of the internal self-reinterpretation of political community, statist cosmopolitanism raises the prospect of overcoming the critique of the state system outlined in the previous section. Perhaps, where the appropriate cosmopolitan selfunderstandings are extant, an anarchical state system no longer presents the same difficulties, since states will not seek advantage at the expense of others and will not appeal to their sovereign status to avoid cosmopolitan obligations. Similarly, collective action problems look more readily solvable, since states will be less inclined to 'free ride' with respect to global 
public goods and will be actively willing to contribute their fair share to the realisation of distributive cosmopolitanism. Furthermore, since states will have collectively reinterpreted their purpose in a cosmopolitan direction, the self-understood purpose of the state will no longer be counter to cosmopolitan ends. Just as the members of a crime syndicate might collectively reject a life of crime and instead direct their energies toward community improvement projects, it might be possible that the citizens of a state come to democratically decide that they wish their association to devote itself to reducing global inequalities and improving the living standards of the globally worst-off - they might decide, that is, that their state should work for the collective benefit of all, and not simply the 'national interest'.

Furthermore, in a world in which all states were committed cosmopolitan agents, the worry that domestic justice need necessarily conflict with cosmopolitan justice seems to dissipate. Such states would commit to the establishment and maintenance of a just 'global background context', within which states' domestic justice efforts would be unproblematic. Of course, "the resource reallocation that this egalitarian international order requires will...entail some reduction in the entitlements of some presently very well-off countries', and some restriction on the right to self-determination; rich governments could not justify devoting resources to narrowing inequalities between individuals within their territories if the appropriate global background context was not in place (Tan, 2004, p. 122; see also Ronzoni, 2009). But in a world of political communities that had undergone cosmopolitan transformations, these restrictions would presumably be accepted by 'responsible cosmopolitan states' (Brown, 2011).

Why, however, should we expect that a political community might actually ever reorient itself toward cosmopolitan principles in this way? Isn't it more reasonable to expect that particularist political communities will continue to deliver ethically particular outcomes? Statist cosmopolitanism's proposed answer is to turn to the role activists can play in alerting citizens to global injustice, 'challenging consent about the function and purpose of existing political institutions and...drawing attention to the need for a new interpretation of their role' (Ypi, 2011, p. 169). The groups in question here are diverse, including large international 
non-governmental organisations, pressure groups, trade unions, religious groups, and amorphous, localised social movements. Rather than be phased by the mammoth task that these groups have ahead of them, statist cosmopolitanism draws an analogy with historically successful activist campaigns such as the abolitionist and women's suffrage movements:

Owing to the activity of political avant-gardes what initially appeared unacceptable to consolidated elites or was considered over-demanding by the larger mass of citizens progressively matured into a persistent popular request for modifying the scope and franchise of democratic citizenship. It is through the construction of similar political initiatives that other fellow-citizens came to progressively sympathise with the suffering of vulnerable subjects and that initially weak moral motives obtained political agency (Ypi, 2010, p. 123).

The claim is that cosmopolitan activists today represent a 'cosmopolitan avant-garde' that can spark debate and ultimately stimulate a cosmopolitan reinterpretation of the purpose of the domestic state. This reinterpretation is to occur reiteratively within state communities, as activists within each state, as part of their agenda-setting and advocacy, translate cosmopolitan arguments into a form that appeals to the particular 'shared schemes of understanding' and cultural-historical reference points found there.

I want to subject the idea of statist cosmopolitanism to critique from two directions: the unlikelihood, as I see it, of the cosmopolitan avant-garde inspiring cosmopolitan transformations of states; and then, setting aside the first critique, the appropriateness of the domestic state system remaining in place even if the avant-garde are indeed successful.

\section{Can the cosmopolitan avant-garde succeed?}

Within statist cosmopolitan theory, the cosmopolitan avant-garde are hypothesised to be able to motivate the reiterative cosmopolitan transformation of states via the strength of cosmopolitan moral argument alone. No appeal is made, for example, to the potential efficacy of self-interested arguments for alleviating global poverty, or of developing affective ties and 
identities across borders. Accordingly, I restrict myself here to consideration of statist cosmopolitanism's 'Kantian' approach, although I in any case believe that alternative potential sources of cosmopolitan motivation themselves necessitate extensive global political integration. ${ }^{4}$

When are activist campaigns successful? Margaret Keck and Kathryn Sikkink's instructive study of transnational activist networks tells us that two factors are most potent: clear and direct physical harm to vulnerable people, 'especially where there is a short and clear causal chain (or story) assigning responsibility'; and the fact of legal inequality (1998, p. 26). Recall that the argument in support of the idea of the cosmopolitan avant-garde points to the historical precedents of the abolition of slavery and women's suffrage. These two cases appear to conform to Keck and Sikkink's analysis: in the case of slavery, there existed both direct physical harm and legal inequality; in the case of women's suffrage the issue was one of clear legal inequality. The discrete campaigns often offered as examples of the cosmopolitan avant-garde in action - e.g. against the maltreatment of children and others working in sweatshops by multinational corporations, or pro-migration movements - also seem to fit into this framework. In the former case there exists a clearly responsible agent (the corporate employer) and a sense in which vulnerable people are being actively exploited (and arguably physically harmed). In the latter case there is again a clear legal inequality in evidence (between citizens of a state and the excluded).

However, as we move beyond certain identifiable 'bad things' being visited upon some by others - slavery, child labour, political violence, the displacement of communities etc. - toward a thoroughgoing vision of global distributive justice, specific perpetrators of injustice become less easy to locate, and causal chains unavoidably become less clear. And when causal chains become less clear, alternative narratives become available. For example, in contrast to those who rally against the perceived unfairness of various international organisations and trade agreements and the purported effect these have on the inhabitants of less powerful countries, it can be - and is - claimed that in fact, global trade agreements have done much to improve the quality of life of many individuals worldwide (Bhagwati, 2004; 
Wolf, 2005). Where people remain in poverty, this might then be attributable to other factors: perhaps the problem is corrupt political elites in poor countries. Maybe poor countries, through political mismanagement and/or a certain socio-political public culture, are collectively responsible for their own plight. After all, there was a time at which the standards of living in, for example, Malaysia and Singapore were comparable, but (so one might argue) through judicious management, the latter has prospered whilst the former has not. ${ }^{5}$ This may present a compelling counter-narrative for individuals in richer countries who will not be keen to have the blame for global poverty laid at their own door if there is a seemingly viable alternative position to endorse.

Keck and Sikkink themselves provide a relevant example of the difficulty faced by activists when causal chains are not obviously observable, stating that

Activists have been able to convince people that the World Bank bears responsibility for the human and environmental impact of projects it directly funds, but have had a harder time convincingly making the IMF responsible for hunger or food riots in the developing world. In the latter case the causal chain is longer, more complex, and much less visible (1998, p. 28).

To be entirely clear, it is not my claim that the truth of the matter regarding the empirical bases of global poverty cannot ultimately be determined. My point is that the complex nature of the situation allows space for alternative narratives to be developed that compete for our attention and are often successful in doing so, even when they are ultimately inaccurate. This is especially so given that some cosmopolitan narratives might be somewhat unpalatable to those to whom they are addressed. For example, one branch of cosmopolitan theorising holds all citizens of richer nations responsible for the currently existing global political system, a system that is said to cause global poverty and inequality (Pogge, 2002). It has been argued that the explication of this causal link should in itself motivate those implicated to remedy the problem (e.g. Dobson, 2006), but in fact, as Iris Young points out, 'frequently the reaction of people being blamed for a wrong is defensive - to look for other agents who should be 
blamed instead of them, or to find excuses that mitigate their liability in those cases where they must agree that their actions do causally contribute to the harm' (2004, p. 318).

It's also worth noting that Keck and Sikkink's findings make grim reading for nonrelational cosmopolitan theory, i.e. theory that arrives at cosmopolitan principles without making reference to a causal or relational link between rich and poor at all. Global luck egalitarianism, for example, has very little fodder to offer the cosmopolitan avant-garde, grounded as it is upon arbitrariness rather than causation. Similarly, an appeal to shared humanity as a reason for including all in the scope of distributive justice (e.g. Caney, 2011) might, even if philosophically convincing, fall flat in practice as appeal to the 'grandest but flimsiest of contemporary imagined communities' (Canovan, 2001: 212).

Whilst the 'visibility' of causal chains presents a difficulty for the avant-garde, it's also the case that the state system itself constitutes a counteracting force that reaffirms particularistic sentiments and related moral beliefs. The job of those wishing to convince us of cosmopolitan principles is to win the argument against alternative attitudes and beliefs (whether those alternatives be clearly theoretically articulated or not); most obviously, cosmopolitan activists must overcome 'associationist' arguments that are articulated by nationalist and statist theorists and which accord with the beliefs of the majority of individuals in richer states today. But in this battle of the arguments cosmopolitans are at a distinct disadvantage. The 'strength of the better argument' might not always win out $-\mathrm{a}$ lot depends on the circumstances in which the argument is being made. Even if we suppose that associationist arguments are ultimately wrong, it's clear that the associationist point of view enjoys high levels of support. This is because - contrary to cosmopolitanism - the thrust of an associationist point of view does not have to be actively presented to individuals (by activists or whoever) for their consideration: it is already internalised by individuals just in virtue of their everyday lived experience as members of different nations, and/or as citizens of different states. Indeed, nationalist theorist David Miller explicitly articulates a methodology that begins from the facts of actually existing sentiments and beliefs and thereafter attempts to construct a theory that incorporates those attitudes; this methodology is contrasted with an 
alternative that pays no heed to 'what the people think' and as such is liable to be viewed negatively as a philosopher's 'external imposition' (1999a, p. 51). When it comes to global justice, one thing people currently tend to believe is that nations are of moral relevance. It is thus not difficult to understand that cosmopolitan theory will often be viewed as this type of external imposition. As Miller characterises it, the theory of nationalism is not exogenously presented to individuals for their consideration; rather, the sociological reality of nationalism informs nationalist theorising. That sociological reality, so many cosmopolitans contend, is a state construction (e.g. Appiah, 1996, p. 27; Axelsen, 2013; Weinstock, 2001).

Statist theorising, while not proceeding via direct reference to what the people already think, does similarly forward arguments that are readily internalised - in their broad thrust at least - by individuals without any need for exogenous and explicit presentation of the argument. Members of a state are made keenly aware, every day, of their relationship to their state: they are aware of their status as citizens and of the benefits and burdens that status brings, and these features of their lives will often seem morally relevant to the scope of justice even if they are not (as non-relational cosmopolitans argue) or are no longer decisive due to other global institutional change (as relational cosmopolitans argue). Every day, their politicians, their media and their fellow citizens subtly reinforce (deliberately or otherwise) a 'banal nationalism' that clarifies their existence as a member of a particular state (Billig, 1995). The artificially-constructed separation from other individuals worldwide 'naturally promotes a bias toward tending to the needs or interests of the citizen set, a bias that is reinforced by mostly inward-looking systems of national public education' (Cabrera, 2004, p. 81). The results of this socialisation are evidenced in, for example, objections voiced in public debates toward overseas aid. If these objections are not informed simply by nationalist sentiment, then they are often framed by appeal to the normative import of the state: we all pay taxes and participate in the same institutional scheme, foreigners don't, so why should our money be sent there rather than spent on problems at home ${ }^{6}$ These sorts of intuitive, reflex reactions to the idea of global distributive justice implicitly hit upon issues such as 
reciprocity, co-authorship and institutional coercion that are articulated explicitly by statist theorists (see, respectively, Sangiovanni, 2007; Nagel, 2005; Blake, 2001).

In contrast to associationist arguments, cosmopolitan arguments often have to be explicitly presented to people in order that they be internalised. For example, complex causal arguments that appeal to unseen and unfelt (by the globally better-off, at least) global processes $d o$ need to be actively presented to us - and it is this presentation that is attempted by the cosmopolitan avant-garde. But these cosmopolitan arguments will be at the forefront of an individual's consciousness only during the time at which the argument is being presented to them (if it is presented at all). Associationist arguments are arrived at autonomously and are felt and lived rather than learnt (although they are also learnt via a process of civic education). What's more, they are felt and lived constantly. These felt and lived attitudes will, for most of us, overcome the 'external imposition' that is irregularly and fleetingly presented by cosmopolitan activists.

Statist cosmopolitanism claims that the state needn't necessarily have the effect of generating and replicating particularist intuitions; instead, the state might be harnessed for cosmopolitan ends because our attachment to our state as a community enables a radical reinterpretation of its purpose. But while it is no doubt true that this attachment would be a potent force if the state came to reinterpret itself in a cosmopolitan direction, my point is that state processes themselves - deliberate or otherwise - seem to stand in the way of that reinterpretation being successfully executed in the first place. None of what I have said here definitively refutes the possibility of avant-garde success. Yet success does seem unlikely, and importantly the main reason for this is the state system itself. This suggests that if cosmopolitan principles are to be widely internalised, there will need to be 'top down' global institutional change as well as 'bottom up' social movements (Ulaş, 2015).

\section{The consequences of avant-garde success}

Notwithstanding my argument above, it is my contention that avant-garde success would in any case lead to an eventual commitment to the transcendence of the domestic state system 
and integration within a federal world state order. To begin to show this I want to return to the idea of the purpose of the state. Suppose that the cosmopolitan avant-garde, over a number of years, score successes globally such that domestic states progressively come to understand their purpose to include fulfilling the demands of cosmopolitan justice between them; they would understand themselves to have the collective duty to realise and sustain a 'just global background context' that, in their view, amounted to global egalitarianism (Tan, 2004). We can assume in this regard that fair terms of economic integration would be adhered to in international institutions and that exploitation would be avoided. States would cease treating each other as competitors over whom they sought to gain advantage.

Even if a cosmopolitan transformation in attitudes and behaviour does occur, however, it is unlikely that a system of multiple states would represent an efficient institutional site for a just global background context of this kind. This is because there would, regardless of states' good intentions, remain various factors that would tend to push the world toward increasing inter-state inequality in a way that would over time translate into normatively troubling individual inequality: ${ }^{7}$ states will still possess differing levels of natural resources that can be utilised or sold for profit; ${ }^{8}$ some states will still find it easier to attract businesses than others, perhaps because they represent a strategically useful location or hospitable climate; states will still be vulnerable to the unpredictable nature of global markets, and will still be indirectly affected by the economic decisions of other states (for example, if one state decides to produce more products of its own rather than import from elsewhere, or to cut business taxes, this may have a knock-on effect on other states which harms their ability to fulfil their own duties); the larger population of some states will still provide a bigger tax base that allows for the undertaking of various projects unavailable to states with smaller populations; states with larger market sizes will still tend toward growth more quickly; agrarian states still might suffer a number of particularly bad years' harvest on account of natural disasters. And so on.

The statist cosmopolitan might accept all this, and claim that none of it is problematic; we need not expect that states offering each other fair terms of cooperation, 
committing to avoid exploitation and so forth will in itself realise a just global order in a stable and on-going manner. All that follows is that states have additional duties to produce this order - and since we are assuming that states have undergone their respective cosmopolitan transformations, they will be willing to take on that task. It's not clear, however, that separate states will be both willing and able to do so. For one thing, the global economy is in significant part out of states' control:

Unless states can effectively control significant aspects of the world economy - such as price, exchange rates (the strength of each currency), capital flows and investment, which sectors of the economy get developed, speed of development, property ownership regimes, and employment patterns - they will not be able to continuously adjust for the consequences of global horizontal impact [i.e. the way accumulated trade transactions, agreements etc. affect global distribution] (Meckled-Garcia, 2008, p. 265). ${ }^{9}$

Without these pervasive controls, any attempts made by states to sustain a just global background context will have unpredictable and imprecise results: it is not credible to believe that states could possess the epistemological capacity to foresee the indirect and complex results of market interactions and decisions and alter their own behaviour accordingly, not least because other states' attempts to do exactly the same thing would need to be factored into any calculation. Within domestic states, either these problems do not apply, or governments do have the appropriate control, or in any case they have 'direct redistributive control on an on-going basis through the distribution of rights and duties' (Meckled-Garcia, 2008, p. 267). Of course, no currently existing agent has these powers at the global level. But, given that we are assuming the motivation exists within each domestic state to realise and maintain distributive cosmopolitanism, the rational thing to do would then seem to be for those states to create the missing centralised agency, thereby unburdening themselves from these difficulties. ${ }^{10}$ If motivated, states can effectively control, for example, exchange rates: they can do so by rejecting a system of separate currencies altogether and developing one 
global currency complete with the necessary accompanying institutions. After all, in a world in which cosmopolitanism has been universally internalised, what positive role do separate currencies and exchange rates play? Why would they be viewed as anything other than an inconvenience that tends towards economic turbulence and inequality (Frankman, 2002)?

An alternative of ongoing transfers of money from richer countries to poorer ones is at best an inefficient way to proceed. A common worry of those opposed to the practice of giving 'aid' is that it can foster dependency in the recipient states. Others worry that movements of money into an economy over prolonged periods can 'cause inflation and its associated problems' (Meckled-Garcia, 2008, p. 265). I cannot hope to comment on whether these technical difficulties are surmountable or not. But even if they are surmountable, they present complex and unnecessary challenges. What would be the point of this indirect method of achieving the desired outcome? Why retain separate economies and continually struggle to reset the inequalities that inevitably arise between individuals globally via a voluntary transference of money between states, rather than develop an administrative system that has a more direct control over the welfare levels of individuals worldwide via its own social and economic policies?

More problematically, however, one can object that the supposed solution of ongoing redistributions of funds from some states to others in other to sustain a fully just global order in fact achieves no such thing: to believe that it would is to ignore the dynamic of power and dependency that remains in play in such a scenario, and that is problematic from the perspective of justice regardless of whether or not that power advantage actually manifests as a material advantage (Forst, 2012; Ronzoni, 2009). This power difference by definition cannot be overcome by anything that the more powerful states decide voluntarily to do (or not do). It can only be overcome by way of the development of formal legal-political institutions at the global level that have direct redistributive control and that fundamentally and effectively rebalance that power difference at its root.

Consider further that we have so far assumed that domestic states and their citizens will always at least be trying to fulfil their cosmopolitan duties after the hypothetical 
cosmopolitan transformation has occurred. But is this in fact a reasonable assumption? Consider the domestic context. It would absurdly optimistic to expect the majority of individuals to voluntarily and consistently adhere to the moral precepts that they recognise intellectually; what Aristotle called akratic action, and which is often today called 'weakness of will' or 'backsliding', is a recognised feature of human experience. The coercive power of the state helps here: we don't have a choice, day-to-day, over whether or not we contribute to a redistributive welfare system, which means we cannot easily 'free ride', backslide or otherwise renege on our responsibilities even if in moments of moral weakness we want to. It is for this reason that Kurt Bayertz calls the modern welfare state an example of 'quasisolidarity' (1999: 24). It does not require our active participation; nor does it allow us the opportunity to fail to live up to its requirements. Cosmopolitans who reject the notion of centralised coercive force at the global level implausibly expect a more demanding variety of political solidarity to hold at the global level than has been achieved in the domestic context.

Recognising the ongoing difficulties presented by the domestic state system, the population of a hypothetical future world which had been convinced of the merits of cosmopolitan distributive justice should be expected to ask itself: what good are separate states? Should they be abandoned? The statist cosmopolitan might reply that they shouldn't, because states are not only potential agents of cosmopolitan justice - they are also communities to which people remain attached, even after a cosmopolitan reinterpretation of that community has occurred. Indeed, recall that it is this attachment to the state as a community that is hypothesised to offer a solution to the problem of cosmopolitan motivation in the first place. However, a federal world state would potentially be able to preserve precisely those elements of a domestic state that are claimed by the statist cosmopolitan to be motivationally efficacious, and would entail no further curtailment of domestic state powers than is in any case demanded by cosmopolitan moral theory itself.

One way of characterising what has happened when states have effected a cosmopolitan transformation is to say that they have rejected the notion of the economic selfdetermination of states, i.e. the idea that if one state becomes richer or poorer than another, it 
is the responsibility of the respective states alone, and the inequality that arises demands no redress (cf. Rawls, 1999; Miller 1999b). Yet we can also point to two other main facets of self-determination, which I will term political and cultural self-determination. Political selfdetermination means the ability of a polity to structure internal relations between individuals in the public sphere as it sees fit, as well as the ability to follow any collective goals or purposes the community may have without outside interference or hindrance (to the extent that those purposes do not interfere with the self-determination of others). Political selfdetermination in fact encompasses many economic decisions: how a political community uses its own resources in a cosmopolitan world is a matter of its own political self-determination. Cultural self-determination refers to the ability of a given polity to live according to its particular public culture(s) without external suppression, and may also involve certain protectionist policies to that end.

It is the political and cultural aspects of the state which the statist cosmopolitan foresees being harnessed by the avant-garde in the pursuit of cosmopolitan transformations. And a federal global order could preserve for federal units (formerly states) some control over these elements. For example, a sensibly constructed global federal state would allow domestic units to retain fully autonomous decision-making capability with respect to localised issues which affected only the residents of that unit (in accordance with a principle of subsidiarity). It could not be the case, of course, that these units retain autonomous decision-making power with respect to actions the effects of which extended beyond the borders of that unit, not least because allowing such a right would infringe upon the self-determination of other units, as global democracy theorists have made clear (e.g. Held, 1995). Nor can it be the case that subglobal political units' right to political self-determination be categorical: in order to be justified from a cosmopolitan perspective, that right to self-determination must go hand-inhand with a commitment to realising a just global order. But cosmopolitans, even statist cosmopolitans, must be committed to these restrictions upon political autonomy; a federal world order therefore need not place any further restriction upon political self-determination than cosmopolitan moral theory itself demands - it merely formalises this restriction. 
With respect to cultural self-determination, a federal state structure could leave decisions regarding official first languages, school curricula, public holidays, and so on in the hands of domestic units. Again, there would of course be a limit to the extent to which a cosmopolitan federal world state would be willing to respect cultural autonomy: clearly, for example, illiberal and hierarchical 'public cultures' could not be tolerated. But again, such cultures are in any case not tolerated by cosmopolitan moral theory itself. Indeed, statist cosmopolitanism must already assume that all domestic states will be transformed by the cosmopolitan avant-garde into liberal egalitarian domestic states, if the theory is to make sense as a potential route to the realisation of cosmopolitan principles. So as with political self-determination, the restrictions placed on cultural self-determination by a federal world order could be understood as legally formalising what is in any case already required by cosmopolitan moral theory.

\section{What are the avant-garde really doing?}

Statist cosmopolitanism characterises the cosmopolitan avant-garde as arguing for the transformation of domestic states via the invocation of a shared historical background and conceptual categories present in the public culture of any one state; those resources are then 'placed at the service of moral learning'. But the avant-garde are just as easily, if not better characterised as a force urging the development of a new global community, and agitating for the transcendence of the domestic state system.

Many of the most plausible candidates for membership of the cosmopolitan avantgarde do not obviously refer back to state-level shared understandings in order to put their points across. Take, for example, the Occupy movement (of American origin) and its frequent rhetorical references to, for example, 'our brothers and sisters in Cairo', or the following from a 'Manifesto for Global Democracy':

Inspired by our sisters and brothers in Tunisia, Egypt, Libya, Syria, Bahrain, New York, Palestine-Israel, Spain and Greece, we too call for a regime change: a global regime change.... Today, like the Mexican Zapatistas, we say " $¡ Y a$ basta! Aquí el pueblo manda y el gobierno obedece": Enough! Here the people command and global institutions obey! Like the Spanish 
Tomalaplaza we say "Democracia Real Ya": True global democracy now! Today we call the citizens of the world: let us globalise Tahrir Square! Let us globalise Puerta del Sol!

(quoted in Suarez and Zameret, 2011)

The aim seems to be precisely to speak to all individuals worldwide at once, and to characterise all as part of the same community (the same demos) at a global level. The quotation above also provides clear evidence that many of the cosmopolitan avant-garde are explicitly agitating for the creation of new global political institutions, and not just the transformation of currently existing states. With this in mind we can contrast statist cosmopolitanism's characterisation of the avant-garde with an alternative approach in which avant-garde activists are understood to be practising 'institutional global citizenship', where this involves advocating the overcoming of the domestic state system and the promotion of global political integration (Cabrera, 2010). This conceptualisation of the work of cosmopolitan activists often fits the reality more accurately.

Characterising the avant-garde as pursuing a strategy of global community development and usurpation of the domestic state system also aids one in confronting the reality that not all societies' shared understandings and wider cultural resources currently contain the sorts of ideas that will in fact aid a cosmopolitan transformation. Not all states are liberal-democratic; some are distinctly hierarchical. In the latter type of state, it is the case that one of the apparently 'shared understandings' within the public political culture is the inequality of individuals. In these cases, what the avant-garde must do first is weaken and ultimately overcome these traditional shared understanding and replace them with egalitarian understandings. This is not to say that activists cannot work to overcome hierarchical understandings without entirely pulling apart a given community that purportedly subscribes to them; but it is to say that much of the activists' work will necessarily be somewhat homogenising in form, narrowing the extent of value diversity in the world, indeed turning the entire global population into liberal egalitarians, and as such may well be said to be aimed at the beginnings of a construction of a new cohesive global community with globally shared values, instead of merely the transformation of old communities. 
By contrast, understanding the cosmopolitan avant-garde simply as reiterative moral persuaders faces another problem. On the statist cosmopolitan account, separate political communities are supposed to reorient themselves toward the realisation of cosmopolitan principles on account of being progressively convinced of the latter's appropriateness. Yet it is often argued that the motivation to realise norms of justice doesn't arise just from being morally persuaded of things, but also from a fund of 'fellow feeling' that pertains between members of a community. This, of course, is precisely the position of liberal nationalist theorists: the nation as a community is said to be of instrumental importance in realising solidaristic outcomes (e.g. Canovan, 1996; Miller, 1995; Tamir, 1993). In retaining the idea of separate political communities to which people are variously attached, statist cosmopolitanism retains the idea that individuals will still feel primary emotional attachment to their own community ahead of others. But if this is the case, and if some of our moral motivation comes not from the acceptance of moral argument but simply from emotional attachment to our community, then there is a clear limit to what the cosmopolitan avant-garde can do. They cannot engender a full, motivationally plausible cosmopolitan reinterpretation of the community because to do so would necessitate forging new global emotional attachments, which would involve the transcendence of particular political communities rather than merely their reinterpretation.

\section{Conclusion}

In conclusion, I want to emphasise the separability of two elements of statist cosmopolitanism: the cosmopolitan avant-garde and the institutional vision. The former refers to the notion of activists effecting cosmopolitan change in and across states. The latter refers to the vision that cosmopolitan justice be realised whilst the multi-state system remains in place in an ongoing sense. Statist cosmopolitanism, as it has been articulated thus far in the literature, seems to me to run both elements together. But it's important to note that one could appeal to the cosmopolitan avant-garde as a route to a cosmopolitan future without endorsing the institutional vision; that is, one could recognise that today's activists might herald a 
coming cosmopolitan future without subscribing to the idea that states - and the communities they contain - will or should continue to exist in the same way once those activists have begun to be successful. ${ }^{11}$

I have sounded a note of strong scepticism regarding the possibilities of success for the avant-garde given the assumption of the continued existence of the state system - my main point was that the state system itself acts as a formidable countervailing force for the avant-garde to overcome, which appears to be another reason to consider the state system part of the problem rather than the solution. This leads to the thought that 'top down' institutional integration at the global level will have to come before, or alongside, the rise of 'bottom up' social movements. Such a thought brings its own concerns, such as how and why global political integration might ever occur in advance of the presence of widespread cosmopolitan sensibilities, and whether such change could occur in morally unproblematic ways.

Even if my scepticism about the powers of the avant-garde proves to be unfounded, however, it doesn't follow that statist cosmopolitanism is right about the institutional vision. Indeed, if the avant-garde succeed in bringing us all around to cosmopolitan moral principles, I have argued that the eventual construction of a global federal order appears to be the likely consequence. This is especially so given the alternative characterisation of the reality of the avant-garde I offered, in which they are understood as seeking the development of a new global community and the transcendence of the domestic state system.

\section{Acknowledgements}

I would like to thank Lea Ypi for several helpful discussions, as well as the paper's anonymous reviewers. This paper was completed while a Postdoctoral Research Fellow at the Centre for Advanced Studies 'Justitia Amplificata', Goethe University, Frankfurt.

\section{Notes}

1. I here understand cosmopolitan justice to be met when the relevant 'distribuenda' are distributed amongst individuals globally in a broadly egalitarian manner. I understand distribuenda widely, to 
potentially encompass, for example, resources, welfare, opportunities, as well as inherently relational concepts like power and recognition. I defend neither a particular conception of cosmopolitan justice nor cosmopolitanism more generally - the latter is simply taken as axiomatic for the purposes of this paper.

2. This paper responds primarily to Lea Ypi's recent thought; indeed, the phrase 'statist cosmopolitanism' is hers $(2008 ; 2011)$. Ypi presents the most fully worked-out positive argument for the domestic state system as a setting for the realisation of distributive cosmopolitanism. However, much of my argument here applies to any theory that wishes to appeal to the potential cosmopolitan transformation of domestic states. For instance, Ypi's argument has similarities with Seyla Benhabib's (2006) notion of 'democratic iteration', as well as Patti Lenard's (2012) reference to the expansionary egalitarian potential of democratic states. Kok-Chor Tan expresses the belief that nation-states can become good cosmopolitan citizens in his Justice Without Borders (2004). For a general appeal for 'bringing the state back in' to cosmopolitan theorising, see Garrett Wallace Brown (2011).

3. While this last addition is less obviously a global public good, there is reason to think that, for example, instability in poor countries threatens richer states' own stability. See Daniel Weinstock (2010).

4. See, for example, Ulaş (2015).

5. For this type of argument see Miller (2007).

6. I do not mean to suggest that either nationalist or statist theorists actually object to foreign aid. Indeed, both tend to believe that there are obligations of justice to relieve severe poverty abroad. My point is that the broad thrust of these positions - i.e. the moral relevance of the nation and/or the state to global justice - are internalised autonomously, simply in virtue of living within the nation-state system. This is true even if the nuanced specifics of those philosophical positions are not grasped in the same way.

7. Given the reality of differing state sizes, global individual equality necessarily entails interstate inequality, but that does not mean that all forms of interstate inequality translate to individual equality. My thought here is that we will see inter-state inequalities arise in a pattern that is not compatible with individual equality.

8. It is true that natural resources are often said to be a 'curse', as countries that depend on the export of natural resources often have authoritarian governments, are plagued by civil war, suffer low levels of growth and high levels of inequality and poverty. But as Leif Wenar (2008) points out, the 'curse' is a symptom of the international rules that allocate control over those resources. In a world of cosmopolitan states, we can assume that these defective rules would be corrected such that it was not possible, for example, for dictators to plunder a country's resources for their own personal benefit.

9. Meckled-Garcia believes that the absence of a currently existing agent capable of competently and authoritatively acting upon a given distributive principle precludes that principle from being the right one. Cosmopolitans, however, do not accept such an 'agency based' approach to justice. For critique of such an approach, see Valentini (2011: 100-107).

10. If it is relational cosmopolitanism that has been internalised, then an alternative might be a mutual commitment amongst states to cease interacting with each other (although it seems rather unlikely that this is possible).

11. For a similar suggestion see Rahul Rao (2013: 103). I go further than Rao in suggesting more strongly that the success of the cosmopolitan avant-garde not only could but, in all likelihood, does entail the transcendence of the domestic state system. While in her 2008 article and in Global Justice and Avant-Garde Political Agency Lea Ypi makes no mention of alternative institutional proposals, in another more recent article (2013) she makes an explicit appeal to the need for 'political cosmopolitanism', referencing favourably recent work on global democracy. Here, the political vision of statist cosmopolitanism is more or less explicitly rejected, and Ypi highlights many of the same problems with the idea of realising global justice through state 'voluntarism' that I referenced in Section 1 of this paper. However, the apparent conflict between the two cosmopolitan institutional visions is not explicitly reconciled.

\section{Note on contributor}

Luke Ulaş is a Postdoctoral Research Fellow at the Centre for Advanced Studies 'Justitia Amplificata: Rethinking Justice, Applied and Global', Goethe University, Frankfurt. 


\section{References}

Appiah, K. A. 1996. 'Cosmopolitan Patriots', in Martha Nussbaum et al, For Love of Country? Boston: Beacon Press

Axelsen, D. V. 2013. 'The State Made Me Do It: How Anti-Cosmopolitanism is Created by the State', Journal of Political Philosophy 21 (4): 451-472.

Bhagwati, J. 2004. In Defence of Globalization. New York: Oxford University Press.

Bayertz, K. 1999. 'Four Uses of "Solidarity"', in Kurt Bayertz (ed.) Solidarity. Dordrecht: Kluwer.

Beitz, C. 1999. 'International Liberalism and Distributive Justice: A Survey of Recent Thought', World Politics, 51: 269-296.

Benhabib, S. 2006. Another Cosmopolitanism (ed. Robert Post). Oxford: Oxford University Press.

Billig, M. 1995. Banal Nationalism. London: SAGE.

Blake, M. 2001. 'Distributive Justice, State Coercion and Autonomy', Philosophy and Public Affairs 30(3): 257-96.

Brown, G.W. 2011. 'Bringing the State Back Into Cosmopolitanism', Political Studies Review, 9: 53-66.

Cabrera, L. 2004. Political Theory of Global Justice. London: Routledge.

2010. The Practice of Global Citizenship. Cambridge: Cambridge University Press.

Caney, S. 2011. 'Humanity, Associations and Global Justice', The Monist 94 (4):506534

Canovan, M. 1996. Nationhood and Political Theory. Cheltenham: Edward Elgar. . 2001. 'Sleeping Dogs, Prowling Cats and Soaring Doves: Three Paradoxes in the Political Theory of Nationhood', Political Studies 49(2): 203-15.

Dobson, A. 2006. 'Thick Cosmopolitanism', Political Studies 54(1): 165-84.

Forst, R. 2012. The Right to Justification. New York: Columbia University Press.

Frankman, M. 2002. 'Beyond the Tobin Tax: Global Democracy and a Global Currency', The ANNALS of the American Academy of Political and Social Science, 581: 62-73.

Held, D. 1995. Democracy and the Global Order. Cambridge: Polity.

Kamminga, M. R. 2006. 'Why Global Distributive Justice Cannot Work', Acta Politica (26) 21-40.

Keck, M and Sikkink, K. 1998. Activists Beyond Borders: Advocacy Networks in International Politics. Ithaca, NY: Cornell University Press.

Lenard, P. T. 2012. 'Creating Cosmopolitans', Critical Review of International Social and Political Philosophy 15(5): 613-30.

Meckled-Garcia, S. 'On the Very Idea of Cosmopolitan Justice', The Journal of Political Philosophy, 16: 245-271

Miller, D. 1995. On Nationality. Oxford: Oxford University Press. .1999a. Principles of Social Justice. Cambridge, MA: Harvard University Press. .1999b. 'Justice and Global Inequality', in Andrew Hurrell and Ngaire Woods (eds.), Inequality, Globalization and World Politics. Oxford: Oxford University Press. 2007. National Responsibility and Global Justice. Oxford: Oxford University Press.

Moellendorf, D. 2005. 'The World Trade Organisation and Egalitarian Justice', Global Institutions and Responsibilities, ed. C. Barry and T. Pogge. Oxford: Blackwell

Nagel, T. 2005. 'The Problem of Global Justice', Philosophy and Public Affairs 33(2): 11347.

Pogge, T. 2002. World Poverty and Human Rights. Cambridge: Polity

Rao, R. 2013. 'Listening to the Avant-Garde', Ethics and Global Politics, 6 (2): 101-107.

Rawls, J. 1999. The Law of Peoples. Cambridge, MA: Harvard University Press.

Ronzoni, M. 2009. 'The Global Order: A Case of Background Injustice? A PracticeDependent Account', Philosophy and Public Affairs 37(3): 229-256.

Sangiovanni, A. 2007. 'Global Justice, Reciprocity and the State', Philosophy and Public Affairs 35(1): 3-39.

Steinberg, R. H. 2002. 'In the Shadow of Law or Power? Consensus-Based Bargaining 
and Outcomes in the GATT/WTO', International Organisation, 56: 339-375.

Suarez, A. S. and Zameret, S. 2011. 'A Manifesto for Regime Change on Behalf of all Humanity', Guardian [online], 14 October, Available from:

http://www.theguardian.com/commentisfree/2011/oct/14/manifesto-global-regimechange

Tamir, Y. 1993. Liberal Nationalism. Princeton: Princeton University Press.

Tan, K. 2004. Justice Without Borders. Cambridge: Cambridge University Press.

Weinstock, D. 2001. 'Prospects for Transnational Citizenship and Democracy', Ethics and International Affairs 15(2): 53-66.

2010. 'Motivating the Global Demos', Global Democracy and Exclusion, ed. R Tinnevelt, R and de Schutter, H. Oxford: Wiley Blackwell

Ulaş, L. 2015. 'Global Community as a Response to the Cosmopolitan Solidarity Problem', in in Henrik Enroth and Douglas Brommesson (eds.) Global Community? Transnational and Transdisciplinary Exchanges. Oxford: Rowman and Littlefield.

Valentini, L. 2011. Justice in a Globalized World. Oxford: Oxford University Press.

Wenar, L. 2008. 'Property Rights and the Resource Curse', Philosophy and Public Affairs 36(1): 2-32.

Wolf, M. 2005. Why Globalization Works. New Haven and London: Yale University Press.

Young, I. R. 2004. 'Responsibility and Global Labour Justice', Journal of Political Philosophy 12: 365-88

Ypi, L. 2008. 'Statist Cosmopolitanism', Journal of Political Philosophy 16(1): 48-71. . 2010. 'Politically Constructed Solidarity: The Idea of a Cosmopolitan Avant-Garde', Contemporary Political Theory 9(1): 120-30. . 2011. Global Justice and Avant-Garde Political Agency. Oxford: Oxford University Press.

2013. 'Cosmopolitanism Without If and Without But', in Gillian Brock (ed.), Cosmopolitanism versus Non-Cosmopolitanism: Critiques, Defences, Reconceptualisations. Oxford: Oxford University Press. 